\title{
LOW-RANK COAL GASIFICATION USING A BUBBLING FLUIDIZED BED REACTOR AT LOW OPERATING TEMPERATURE
}

\author{
GASIFIKASI BATUBARA PERINGKAT RENDAH MENGGUNAKAN \\ REAKTOR BUBBLING FLUIDIZED BED \\ PADA SUHU RENDAH
}

\author{
SAPTA RIANDA, DEDY YASKURI and M. ADE A. EFENDI \\ Research and Development Centre for Mineral and Coal Technology \\ Jalan Jenderal Sudirman 623 Bandung 40211 \\ Ph. (+6222) 6030483, Fax. (+6222) 6003373 \\ e-mail: sapta rianda@yahoo.com
}

\begin{abstract}
Coal gasification is one of coal utilizations that produces less $\mathrm{CO}_{2}$ emission than coal combustion. Coal gasification technology that has been used in Indonesia is generally a fixed bed gasification. Fixed bed is designed for high-rank coal and the majority of Indonesian coal is of a low-rank. Low ash and high moisture content of the Indonesian coal in a fixed bed can affect mechanical and thermal fragmentation, pressure drop, gas and particle flow distribution. The operation of gasifier may cause unstable condition. Another gasification technology is bubbling fluidized bed, which is operated above $1,200^{\circ} \mathrm{C}$, so ash can melt. High operating temperature causes agglomeration and makes unstable gasification process. Therefore, in this study, low-rank coal is gasified in bubbling fluidized bed reactor at low operating temperature. The purpose of this study is to determine the optimal conditions of bubbling fluidized bed gasification. The research was conducted in bubbling fluidized bed coal gasification Process Development Unit (PDU) at Coal Utilization Technology Centre of R\&D Centre of tekMIRA, Palimanan. Coal was fed continuously as many as $20 \mathrm{~kg} / \mathrm{hour}$ into a gasifier then was gasified to produce gas using air as a gasifying agent and silica sand as a bed material at $850-950^{\circ} \mathrm{C}$. The produced gas from the gasification was analyzed using the Orsat Analyzer. A simulation using a ChemCAD 7.1 CC steady state was applied to validate the experiment result. From the analyzed result of yield gas composition, the produced $\mathrm{CO}$ and $\mathrm{CO}_{2}$ were about $10-15 \mathrm{wt} \%$. Gas compositions that are close to criteria of producer gas, no agglomeration, and stable process condition during study indicate that bubbling fluidized bed gasification at low operating temperature is suitable to be applied as gasification technology for Indonesian low-rank coal.
\end{abstract}

Keywords: low-rank coal, gasification, bubbling fluidized bed, producer gas

\begin{abstract}
ABSTRAK
Gasifikasi batubara merupakan salah satu pemanfaatan batubara yang menghasilkan lebih sedikit emisi $\mathrm{CO}_{2}$ jika dibandingkan dengan pembakaran. Teknologi gasifikasi batubara yang telah banyak digunakan di Indonesia adalah teknologi fixed bed, namun teknologi tersebut dirancang untuk batubara peringkat tinggi yang tidak cocok untuk mayoritas batubara Indonesia yang merupakan batubara berperingkat rendah. Abu rendah dan kandungan air yang tinggi pada batubara Indonesia menyebabkan terjadinya fragmentasi mekanik dan termal batubara, sehingga distribusi ukuran partikel dan gas tidak merata, terjadi pressure drop, dan proses gasifikasi tidak stabil. Teknologi lainnya adalah bubbling fluidized bed yang dioperasikan di atas suhu $1.200^{\circ} \mathrm{C}$ agar abu yang dihasilkan dapat mencair. Kondisi operasi pada suhu tinggi ini menyebabkan aglomerasi sering terjadi, sehingga mengganggu proses gasifikasi. Oleh karena itu, pada penelitian ini dilakukan gasifikasi batubara peringkat rendah pada reaktor bubbling fluidized bed yang beroperasi pada suhu rendah. Tujuan penelitian ini adalah untuk mengetahui kondisi optimal gasifikasi bubbling fluidized bed. Penelitian dilakukan di Process Development Unit (PDU) gasifikasi bubbling fluidized bed di Sentra Teknologi Pemanfaatan Batubara Tekmira, Palimanan. Batubara yang diumpankan sebanyak $20 \mathrm{~kg} / \mathrm{jam}$ secara menerus, lalu digasifikasi menggunakan udara sebagai penggasifikasi dan pasir silika sebagai bed
\end{abstract}


material pada suhu $850-950^{\circ} \mathrm{C}$. Gas yang terbentuk akan dianalisis menggunakan Orsat. Simulasi ChemCAD 7.1 CC steady state digunakan untuk memvalidasi hasil penelitian. Dari komposisi gas yang dihasilkan diperoleh $\mathrm{CO}$ dan $\mathrm{CO}_{2}$ sekitar 10-15 wt\%. Komposisi gas yang sudah mendekati kriteria gas produser, tidak ada aglomerasi, dan kondisi proses stabil selama penelitian mengindikasikan bahwa gasifikasi bubbling fluidized bed yang beroperasi di suhu rendah cocok diterapkan sebagai teknologi gasifikasi untuk batubara Indonesia yang berperingkat rendah.

Kata kunci: batubara peringkat rendah, gasifikasi, bubbling fluidized bed, gas produser

\section{INTRODUCTION}

The utilization of coal in power generation by burning such the coal to generate electricity is cheaper than other fuels, except natural gas, but $\mathrm{CO}_{2}$ emissions that generated is higher than the others (Towler, 2014). $\mathrm{CO}_{2}$ emissions from coal combustion take up over $40 \%$ of global $\mathrm{CO}_{2}$ emissions (Bu et al., 2014). In 2012, Indonesia was included in the top 5 emitter countries in the world (Dutu, 2016). One of $\mathrm{CO}_{2}$ reducing technologies, especially in power generation section, is gasification by converting coal to be producer gas, consisting of $\mathrm{CO}, \mathrm{H}_{2}$, and $\mathrm{CH}_{4}$. (Rachmatullah, Aye and Fuller, 2007).

Producer gas from coal gasification has been widely used for generating electricity in gas turbine or a combination of gas turbine and steam turbine. Although the heating value of producer gas is much lower than that of the heating value of natural gas, the air required to burn producer gas is much lower than natural gas and diesel fuel (Taha, Abdel-Salam and Vellakal, 2013).

Coal gasification processes are drying, pyrolysis, oxidation, and reduction (Patel, Upadhyay and Patel, 2014). In the drying process, moisture/water particles present in coal gets vaporized. Pyrolysis process is set of complex reaction involves heating solid fuel to produce char and release volatiles. In oxidation process, char and volatiles are combusted with oxygen to produce the necessary gasifying agents (steam and $\mathrm{CO}_{2}$ ) and $\mathrm{CO}$. This reaction is exothermic and released heat is used for reduction reactions.

The main gasification reaction is the reduction. Char, tar, and hydrocarbon are gasified with $\mathrm{CO}_{2}$ and steam to produce gas, which is composed mainly of $\mathrm{CO}, \mathrm{H}_{2}$, and $\mathrm{CH}_{4}$. The reactions are endothermic and require the heat produced from the prior oxidation reactions. Steam promotes the steam reforming (endothermic) of char and tar, as well as water-gas shift reactions (exothermic). $\mathrm{CO}_{2}$ promotes the Boudouard reaction (endothermic) to produce $\mathrm{CO}$ (Qian et al., 2013). Chemically, coal gasification involves the thermal decomposition of coal and the reaction of the coal carbon and other pyrolysis products with oxygen, water, and fuel gas such as methane (Table 1).

Coal gasification technology consists of fixed or moving bed, fluidized bed, and entrained bed gasification (Zeng et al., 2014). Each type of gasifier may be designed to operate at either atmospheric pressure or high pressure. High-pressure systems may have problem associated with the introduction of the feedstock into reactor (Speight, 2014).

Table 1. Gasification reactions

\begin{tabular}{ll}
\hline & Reaksi \\
\hline $2 \mathrm{C}+\mathrm{O}_{2} \rightarrow 2 \mathrm{CO}$ & \\
$\mathrm{C}+\mathrm{O}_{2} \rightarrow \mathrm{CO}_{2}$ & \\
$\mathrm{C}+\mathrm{CO}_{2} \rightarrow 2 \mathrm{CO}$ & \\
$\mathrm{CO}+\mathrm{H}_{2} \mathrm{O} \rightarrow \mathrm{CO}_{2}+\mathrm{H}_{2}$ & Shift reaction \\
$\mathrm{C}+\mathrm{H}_{2} \mathrm{O} \rightarrow \mathrm{CO}+\mathrm{H}_{2}$ & Water gas reaction \\
$\mathrm{C}+2 \mathrm{H}_{2} \rightarrow \mathrm{CH}_{4}$ & \\
$2 \mathrm{H}_{2}+\mathrm{O}_{2} \rightarrow 2 \mathrm{H}_{2} \mathrm{O}$ & \\
$\mathrm{CO}+3 \mathrm{H}_{2} \rightarrow \mathrm{CH}_{4}+\mathrm{H}_{2} \mathrm{O}$ & Methanation \\
$\mathrm{CO}_{2}+4 \mathrm{H}_{2} \rightarrow \mathrm{CH}_{4}+2 \mathrm{H}_{2} \mathrm{O}$ & reaction \\
$\mathrm{C}+2 \mathrm{H}_{2} \mathrm{O} \rightarrow 2 \mathrm{H}_{2}+\mathrm{CO}_{2}$ & \\
$\mathrm{CH}_{4}+2 \mathrm{H}_{2} \mathrm{O} \rightarrow \mathrm{CO}_{2}+4 \mathrm{H}_{2}$ & \\
\hline
\end{tabular}

Source: Speight (2015)

Fixed bed gasification has been widely used in Indonesia, because the fixed bed cost investment is cheaper than other gasification technology (Rubin, Chen and Rao, 2007). However, the fixed bed is an import technology that is designed for high-rank coal, while the majority of Indonesian coal is low-rank (low ash and high moisture) and tar production is higher than that of other technology. Low ash and high moisture content of Indonesian coal in the fixed bed can affect mechanical and thermal 
fragmentation, pressure drop, gas and particle flow distribution. The operation of gasifier may become unstable (Luckos and Bunt, 2011).

Another gasification technology is bubbling fluidized bed, operated at above $1,200^{\circ} \mathrm{C}$, so th ash can melt and forms a liquid slag. This slag must remain in the fluid phase throughout the gasifier and be removed continuously at the bottom slagging reactor. However, it seems to be difficult for the operation, because reactor must be in high temperature and if gasification uses a catalyst, recovering is impossible under slagging conditions. The two most important parameters in slagging bubbling fluidized bed are temperature and mineral, because they determine the slag flow parameter, such as viscosity. The operating temperature is limited by ash fusion temperature test (AFT). So, the temperature of the gasifier must be below the AFT to prevent melting of coal ash that can cause a slagging in gasifier. In addition, the operating temperature of the gasifier is also limited by the melting point of the bed material. The formation of low melting point inorganic compounds in the ash can form agglomeration and this leads the entire bed defluidizing, due to the presence of large agglomerates (van Eyk et al., 2016). Silica reaction in sand and sodium within the ash is the main cause for agglomeration (Song et al., 2016). Controlling slag viscosity is not easy, because if too low, the slag velocity increases and the insulation may be lost. If too high, such the slag may accumulate on the walls and forms agglomeration (Tremel et al., 2013).

Based on the fact that the majority of Indonesian coal is a low-rank coal (low ash and high water content), fixed bed gasification and bubbling fluidized bed at high temperatures are not suitable. Referring to such a predicament, this research gasification of bubbling fluidized bed operated at low operating temperature was conducted to eliminate the problem that arises because of slagging and to answer wich the most appropriate gasification technology for Indonesian low-rank coal.

\section{METHOD}

Materals ued for ti experients beln to a lowrank coal. Silica sand was used a bed material. Characterization of these materials included proximate and ultimate of coal, particle size, and ash fusion temperature test (AFT).

The research was conducted in bubbling fluidized bed coal gasification Process Development Unit (PDU) at Coal Utilization Technology Centre of R\&D Centre of tekMIRA, Palimanan. The PDU consists of reactor, feeding system, cyclone separator, and producer gas tank. Equipment specifications can be seen in Table 2.

Table 2. Equipment spesification

\begin{tabular}{lc}
\hline \multicolumn{1}{c}{ Equipment } & Specification \\
\hline Reactor & \\
Volume, $\mathrm{m}^{3}$ & 0.41 \\
Inside diameter, $\mathrm{m}$ & 0.36 \\
Height, m & 4 \\
Blower & \\
Power, kW & 7.5 \\
Maximum capacity, kPa G & 5 \\
Bed section & \\
Bed height, m & 0.18 \\
Nozzle, pc & 42 \\
\hline
\end{tabular}

Figure 1 shows the flow diagram of bubbling fluidized bed gasification process. Coal was gasified using air and silica sand as bed material (Harris and Roberts, 2013; Speight, 2014; Mahinpey and Gomez, 2016).

Coal was continuously fed as many as 20 $\mathrm{kg} / \mathrm{hr}$ into the reactor using a screw feeder. The reactor was operated at $850-950^{\circ} \mathrm{C}$ and $1 \mathrm{~atm}$. The air velocity was measured using orifice in the air pipeline. Pressure gauges were installed on the bottom and above the bed to determine fluidization by observing the pressure drop. The producer gas formed from gasification was flowed to Flare 1 or 2 then was analyzed using the Orsat Analyzer to determine $\mathrm{CO}, \mathrm{CO}_{2}$, and $\mathrm{O}_{2}$ composition.

Simulation using ChemCAD 7.1 CC in steady state was applied to validate the result of the experiment. 


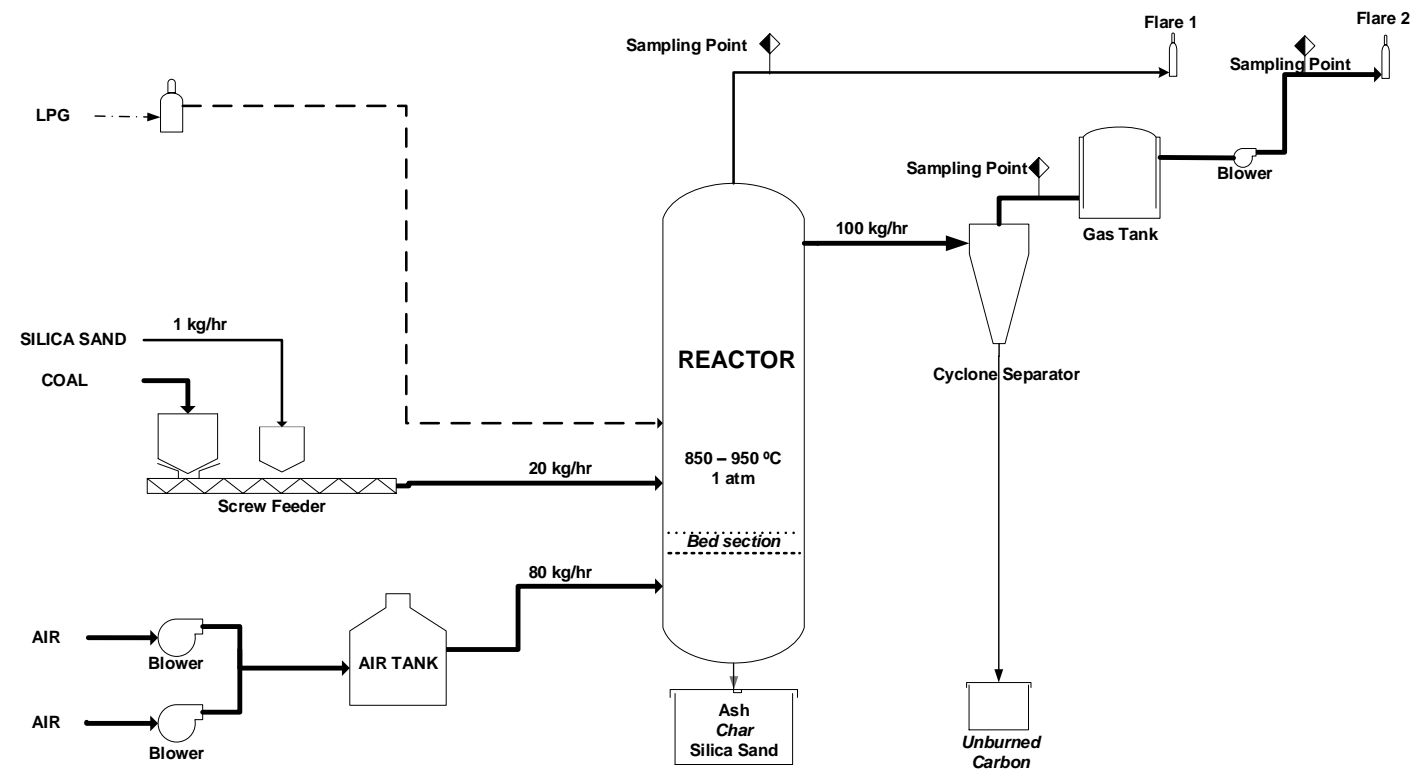

Figure 1. Process flow diagram of bubbling fluidized bed gasification

\section{RESULTS AND DISCUSSION}

\section{Coal Characterization}

Table 3 shows coal proximate analysis of total moisture analysis using the ASTM D.3302, ASTM D.3174 for ash analysis, ISO 562 for volatile matter analysis, ASTM D.3172 for fixed carbon analysis, and ASTM D.5885 for calorific value analysis.

Table 3. Proximate analysis of coal

\begin{tabular}{ccccc}
\hline $\begin{array}{c}\text { Total } \\
\text { Moisture } \\
\%, \text { ar }\end{array}$ & $\begin{array}{c}\text { Ash } \\
\%, \\
\text { adb }\end{array}$ & $\begin{array}{c}\text { Volatile } \\
\text { Matter } \\
\% \text { adb }\end{array}$ & $\begin{array}{c}\text { Fixed } \\
\text { Carbon } \\
\%, \text { adb }\end{array}$ & $\begin{array}{c}\text { Calorific } \\
\text { Value } \\
\text { cal } / g, \\
\text { adb }\end{array}$ \\
\hline 39.04 & 7.28 & 44.03 & 35.62 & 4,962 \\
\hline
\end{tabular}

Table 4 shows coal ultimate analysis of analysis of carbon, hydrogen and nitrogen based on the ASTM D.5373, ASTM D.4239 for sulfur analysis, and ASTM D.3176 for oxygen. The size of coal particles is 45 to 18 mesh, while the bed material is 45 to 20 mesh.

Table 4. Proximate analysis of coal

\begin{tabular}{ccccc}
\hline $\mathrm{C}$ & $\mathrm{H}_{2}$ & $\mathrm{~N}_{2}$ & $\mathrm{~S}$ & $\mathrm{O}_{2}$ \\
$\%, \mathrm{adb}$ & $\%, \mathrm{adb}$ & $\%, \mathrm{adb}$ & $\%, \mathrm{adb}$ & $\%, \mathrm{adb}$ \\
\hline 55.58 & 5.45 & 0.8 & 0.18 & 30.71 \\
\hline
\end{tabular}

Table 5 shows the AFT analysis based on the ASTM D.1857 of the coal and silica sand to determine their melting point.

Table 5. Ash fusion temperature in reducing atmosphere

\begin{tabular}{lcccc}
\hline Sampel & $\begin{array}{c}\text { Deformation } \\
{ }^{\circ} \mathrm{C}\end{array}$ & $\begin{array}{c}\text { Spherical } \\
{ }^{\circ} \mathrm{C}\end{array}$ & $\begin{array}{c}\text { Hemisfire } \\
{ }^{\circ} \mathrm{C}\end{array}$ & $\begin{array}{c}\text { Flow } \\
{ }^{\circ} \mathrm{C}\end{array}$ \\
\hline Coal & 1,180 & 1,205 & 1,225 & 1,280 \\
Silica & 1,565 & - & - & - \\
sand & & - & & - \\
\hline
\end{tabular}

The percentage of total moisture shown in Table 2 is 39.04 wt\%. Total moisture shows water in all forms that resides within the coal matrix (Coppola et al., 2014). In gasification process, the total moisture content will affect gasification efficiency. Total moisture content will lower the energy content of gasification product, because some of the energy will be consumed for water evaporation. Total moisture content can also lower the temperature that leads the increase of tar composition. However, for some conditions processes, the presence of moisture is desired or even essential (Siedlecki, 2011). Total moisture can be used to control the process temperature and it can be hydrogen source to improve producer gas quality. 
Coal used in this experiment contains 44.03 wt\% of volatile matter (VM). The VM acts as an energy provider in the gasification process. VM analysis was conducted to determine the probability of caking or agglomeration of coal. VM value is related to coal rank and commonly used in many empirical correlations to estimate the coal properties e.g., density and specific heat capacity (Towler, 2014). Compositions of fixed carbon and ash are 35.62 wt $\%$ and 7.28 wt\%, respectively. Fixed carbon has relevance to the residence time of the particles in the reactor, because the reaction of carbon is the limiting step in several gasification processes (Judex, Gaiffi and Burgbacher, 2012).

Ash refers to inorganic part of coal. In analytical chemistry, it stands for the remaining solid matter after completing oxidation of the combustible fraction, mostly consisting of metal oxides. The stability condition of ash is related to the behavior of ash fusion temperature (AFT), which will determine the temperature limit of the gasification process (Miller, 2005). The ash content of coal also has an influence on the gasification process. A high amount of ash will lower the energy content of coal and may cause handling problems during and after gasification process. This energy consumption will impact the efficiency of the process. The ash content will also affect the initial preparation of the process (such as grinding), ash handling, and transportation costs. Ash components can also meet devolatilization during the gasification process that would lead to various problems of fouling in the gas cooling system. Ash devolatilization causes corrosion on some equipment. In addition, the ash particles can affect the particle size distribution in the gasifier and can generate agglomeration and sintering.

\section{Operation and Process Performance Parameters}

The bed material in a fluidized bed gasifier was used for heat transfer media from exothermic reaction (combustion) to endothermic reaction (gasification). The bed material in gasifier can improve the quality of heat and mass transfer in the gasifier and prevent the hot/cold spot. Bed material will be fluidized above the minimum fluidization velocity to achieve a bubbling condition that can be observed from pressure change of gasifier as shown in Figure 2. In this experiment, the bed material begins to enter bubbling zone when the air velocity was approximately $1 \mathrm{~m} / \mathrm{s}$ and it reach stable condition at $1.38 \mathrm{~m} / \mathrm{s}$ of air velocity.

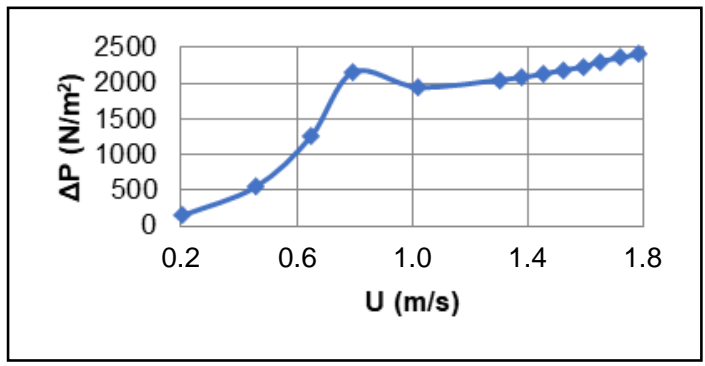

Figure 2. The correlation of air flowrate and pressure drop

At start up, 4 to $25 \mathrm{~kg} / \mathrm{hr}$ of coal was fed to gasifier as shown in Figure 3 . The steady state condition for temperature of 850-950 ${ }^{\circ} \mathrm{C}$ was achieved when the coal feed was 20 $\mathrm{kg} / \mathrm{hr}$. By considering the accumulation during the experiment, the coal was fed at $20 \mathrm{~kg} / \mathrm{h}$, so the temperature conditions of $850-950{ }^{\circ} \mathrm{C}$ remain stable. In addition, operating conditions were limited by melting point of coal ash to prevent agglomeration (Harris and Roberts, 2013). Low operating temperature becomes one of the parameters that causes the bubbling fluidized bed is suitable for lignite/low rank coal, which has low calorific value and high moisture content.

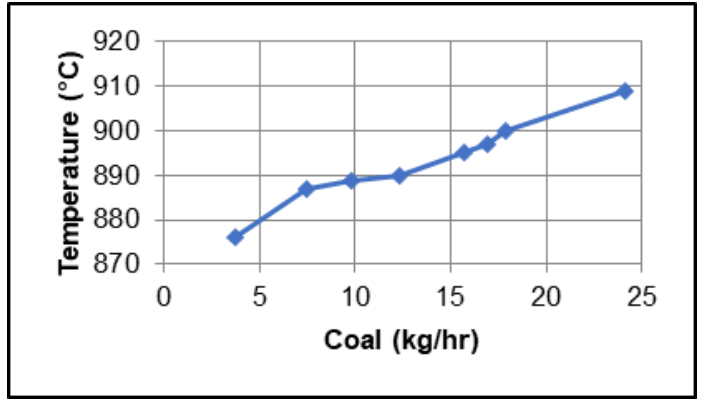

Figure 3. The correlation of coal feed with reactor temperature

From the correlation of reactor temperature and gas composition shown in Figure 4, the $\mathrm{CO}$ and $\mathrm{CO}_{2}$ produced were almost the same. It is $10-15 w t \%$. This shows that the 
gasification is not optimal because the $\mathrm{CO}$ in gasification can be above $20 \mathrm{wt} \%$. There are several factors that influence the quality of produced gas i.e. the ratio between air and coal, which is above the gasification ratio, the reduced bed height (Manyà et al., 2006), unburned carbon (Bell et al., 2011), and bubbling which is expected to distribute the air does not occur.

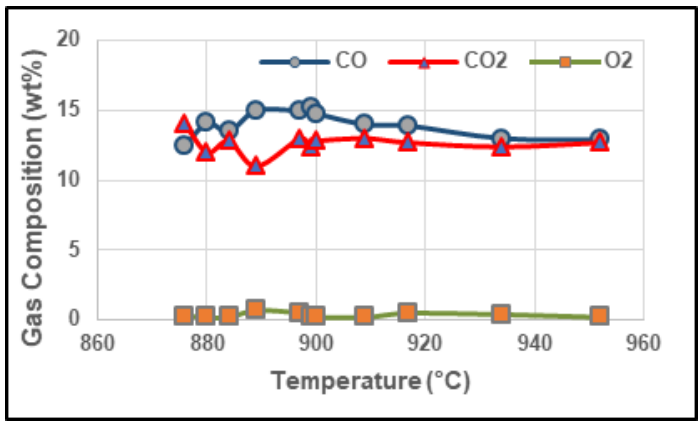

Figure 4. The correlation of reactor temperature and gas composition

Figure 5 shows the results of coal gasification simulations using a ChemCAD. The highest $\mathrm{CO}$ content of this study, which is $15 \mathrm{wt} \%$, is obtained when the coal is gasified by $80 \mathrm{~kg} / \mathrm{hour}$ of air. This condition can be optimized, if the coal feed is reduced so the resulted $\mathrm{CO}$ can be more than 15 wt\%. The optimum conditions based on such a simulation are achieved when the air is $60 \mathrm{~kg} / \mathrm{hr}$ according to the air coal ratio. The air coal ratio for gasification is 1:3 (Bell, Towler and Fan, 2011; Harris and Roberts, 2013; Zeng et al., 2014; Speight, 2015). If the air was below $60 \mathrm{~kg} / \mathrm{hr}$, the unconverted carbon will increase and accumulate in the reactor, thus disrupting the stability of the gasification process.

\section{Agglomeration in Bubbling Fluidized Bed Coal Gasification}

During the experiment, the operating temperature of gasifier was also tested above $950^{\circ} \mathrm{C}$ to find out what phenomena will occur in the gasifier. From the experiment result, it was known that the agglomeration occurs in the gasifier, if the operating temperature reached the ash fusion temperature (above $1200^{\circ} \mathrm{C}$ ). Mahinpey and Gomez experiment concluded that the safety operating temperature of gasifier is $200^{\circ} \mathrm{C}$ below AFT, so the recommended temperature of bubbling gasifier is between $850-950^{\circ} \mathrm{C}$ (Mahinpey and Gomez, 2016).

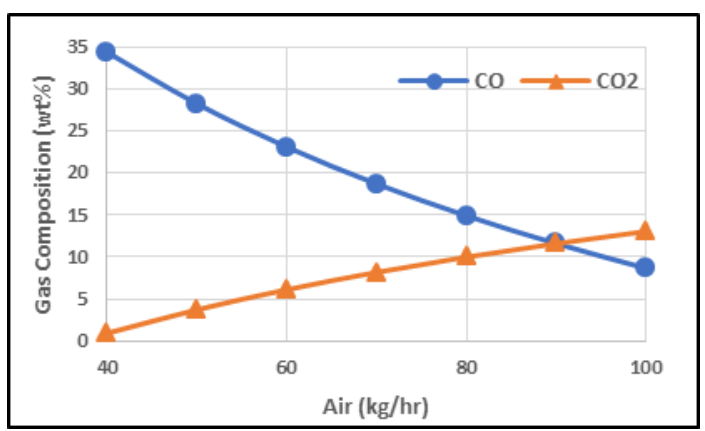

Figure 5. The correlation of air flowrate with $\mathrm{CO}$ and $\mathrm{CO}_{2}$ content

\section{CONCLUSION AND SUGGESTION}

Gasification of the Indonesian low-rank coal using fluidized bed bubbling reactor at low operating temperature of $850-950^{\circ} \mathrm{C}$ at 20 $\mathrm{kg} / \mathrm{hr}$ of coal feed has run smoothly, though the CO content only reaches $15 \mathrm{wt} \%$. The $\mathrm{CO}$ content is lower than that in a fixed or bubbling fluidized bed gasifiers at high temperature. Further research on bubbling fluidized beds operated at low temperature is required to obtain an optimal air-coal ratio to get the CO content more than $20 \mathrm{wt} \%$.

\section{ACKNOWLEDGEMENTS}

The author would like to thank the R\&D Centre for Mineral and Coal Technology (tekMIRA), Ministry of Energy and Mineral Resources, who has funded this research. Thanks also given to fluidized bed gasification team for their contribution during this research.

\section{REFERENCES}

Bell, D. A., Towler, B. F. and Fan, M. (2011) 'Gasifiers', in Coal Gasification and Its Applications. Elsevier, pp. 73-100. doi: 10.1016/B978-0-8155-2049-8.10004-X.

Bu, C. et al. (2014) 'Ignition behavior of single coal particle in a fluidized bed under O2/CO2 and O2/N2 atmospheres: A combination of visual image and particle temperature', Applied Energy, 115, pp. 301-308. doi: 10.1016/j.apenergy.2013.10.040. 
Coppola, A. et al. (2014) 'Hydration-induced reactivation of spent sorbents for fluidized bed calcium looping (double looping)', Fuel Processing Technology, 120, pp. 71-78.

doi: 10.1016/j.fuproc.2013.12.004.

Dutu, R. (2016) 'Challenges and policies in Indonesia's energy sector', Energy Policy, 98, pp. 513-519. doi: 10.1016/j.enpol.2016.09.009.

van Eyk, P. J. et al. (2016) 'Control of agglomeration during circulating fluidized bed gasification of a South Australian low-rank coal: Pilot scale testing', Energy \& Fuels, 30(3), pp. 1771-1782. doi: 10.1021/acs.energyfuels.5b02267.

Harris, D. J. and Roberts, D. G. (2013) 'Coal gasification and conversion', in The Coal Handbook: Towards Cleaner Production. Elsevier, pp. 427-454. doi: 10.1533/9781782421177.3.427.

Judex, J. W., Gaiffi, M. and Burgbacher, H. C. (2012) 'Gasification of dried sewage sludge: Status of the demonstration and the pilot plant', Waste Management, 32(4), pp. 719-723.

doi: 10.1016/j.wasman.2011.12.023.

Luckos, A. and Bunt, J. R. (2011) 'Pressure-drop predictions in a fixed-bed coal gasifier', Fuel, 90(3), pp. 917-921. doi: 10.1016/j.fuel.2010.09.020.

Mahinpey, N. and Gomez, A. (2016) 'Review of gasification fundamentals and new findings: Reactors, feedstock, and kinetic studies', Chemical Engineering Science, 148, pp. 14-31. doi: 10.1016/j.ces.2016.03.037

Manyà, J. J. et al. (2006) 'Influence of gas residence time and air ratio on the air gasification of dried sewage sludge in a bubbling fluidised bed', Fuel, 85(14-15), pp. 2027-2033.

doi: 10.1016/j.fuel.2006.04.008.

Patel, V. R., Upadhyay, D. S. and Patel, R. N. (2014) 'Gasification of lignite in a fixed bed reactor: Influence of particle size on performance of downdraft gasifier', Energy, 78, pp. 323-332. doi: 10.1016/j.energy.2014.10.017.

Qian, F. et al. (2013) 'Development of a kinetic model for industrial entrained flow coal gasifiers', Industrial \& Engineering Chemistry Research, 52(5), pp. 18191828. doi: 10.1021/ie301630x.
Rachmatullah, C., Aye, L. and Fuller, R. J. (2007) 'Scenario planning for the electricity generation in Indonesia', Energy Policy, 35(4), pp. 2352-2359. doi: 10.1016/j.enpol.2006.08.015.

Rubin, E. S., Chen, C. and Rao, A. B. (2007) 'Cost and performance of fossil fuel power plants with $\mathrm{CO} 2$ capture and storage', Energy Policy, 35(9), pp. 4444-4454. doi: 10.1016/j.enpol.2007.03.009.

Siedlecki, M. (2011) On the gasification of biomass in a steam-oxygen blown CFB gasifier with the focus on gas quality upgrading: Technology background, experiments and mathematical modeling. Delft University of Technology.

Song, G. et al. (2016) 'Slagging characteristics of Zhundong Coal during Circulating Fluidized Bed Gasification', Energy \& Fuels, 30(5), pp. 3967-3974. doi: 10.1021/acs.energyfuels.6b00503.

Speight, J. G. (2014) 'Gasifier Types', Gasification of Unconventional Feedstocks. doi: 10.1016/B978-0-12-799911-1.00003-0.

Speight, J. G. (2015) 'Gasification Reaction Kinetics for Synthetic Liquid Fuel Production', in Gasification for Synthetic Fuel Production. Elsevier, pp. 103-117. doi: 10.1016/B978-0-85709-802-3.000059.

Taha, A. T., Abdel-Salam, T. M. and Vellakal, M. (2013) 'Alternative fuels for internal combustion engines: An overview of the current research', in Alternative Fuels Research Progress. 1st edn. International Energy and Environment Foundation, pp. 279-306.

Towler, B. F. (2014) 'Coal and clean coal technologies', in The Future of Energy. Elsevier, pp. 273-299. doi: 10.1016/B978-0-12-801027-3.000130 .

Tremel, A. et al. (2013) 'Performance of entrained flow and fluidised bed biomass gasifiers on different scales', Energy Conversion and Management, 69, pp. 95-106. doi: 10.1016/j.enconman.2013.02.001.

Zeng, X. et al. (2014) 'Pilot verification of a low-tar two-stage coal gasification process with a fluidized bed pyrolyzer and fixed bed gasifier', Applied Energy, 115, pp. 9-16. doi: 10.1016/j.apenergy.2013.10.052. 
